\title{
Pesticide-Induced Physiological, Metabolic and Ultramorphological Alterations in Leaves of Young Maize Seedlings
}

\author{
Mei Lei', Irum Raza', Farah Deeba ${ }^{2}$, Muhammad Jamil'², Rehan Naeem², \\ Azizullah Azizullah ${ }^{3}$, Baharullah Khattak ${ }^{4}$, Azizullah Shah ${ }^{5}$, Imran Ali², \\ Zhu Shui Jin ${ }^{1 *}$, Muhammad Daud Khan ${ }^{1,2 * *}$ \\ ${ }^{1}$ Institute of Crop Science, Department of Agronomy, College of Agriculture and Biotechnology, \\ Zijingang Campus, Zhejiang University, Hangzhou, P.R. China \\ ${ }^{2}$ Department of Biotechnology and Genetic Engineering, Kohat University of Science and Technology, Pakistan \\ ${ }^{3}$ Department of Botanical and Environmental Sciences, Kohat University of Science and Technology, Pakistan \\ ${ }^{4}$ Department of Microbiology, Kohat University of Science and Technology, Pakistan \\ ${ }^{5}$ Natural Resource Division, Pakistan Agricultural Research Council (PARC), Islamabad, Pakistan
}

Received: 7 February 2019

Accepted: 24 April 2019

\begin{abstract}
Pesticides are usually used to eliminate weeds and insects to improve crop quality and yield. The present study was undertaken to explore pesticides (Lambda cyhalotherin (LC) and Emamectin benzoate (EB)) related physiological, biochemical and ultrastructural changes in leaves of maize seedlings at different concentrations of $\mathrm{LC}$ and $\mathrm{EB}$ both singly $\left(\mathrm{LC}_{100}, \mathrm{LC}_{500}, \mathrm{LC}_{800}, \mathrm{~EB}_{100}, \mathrm{~EB}_{300}\right.$, $\left.\mathrm{EB}_{600} \mathrm{mg} / \mathrm{L}\right)$ and jointly $\left(\mathrm{LC}_{500}+\mathrm{EB}_{300} \mathrm{mg} / \mathrm{L}\right)$ along with control. Germination percentage, root stem and leaf lengths increased at lower concentrations of both pesticides and significantly decreased with the increase in the external application of pesticides. At higher concentrations of $\mathrm{LC}$ and $\mathrm{EB}$ (i.e., $\mathrm{LC}_{800}$ and $\mathrm{EB}_{600 \mathrm{mg} / \mathrm{L}}$ ) the mean values of growth and biomass of maize leaves were lower than control. Also, decreases in photosynthetic pigments and ion concentration of $\mathrm{Na}^{1+}, \mathrm{Ca}^{2+}$ and $\mathrm{K}^{1+}$ were significant when the concentration of both pesticides increased. The melondialdehyde (MDA) contents decreased, while the amount of hydrogen peroxide $\left(\mathrm{H}_{2} \mathrm{O}_{2}\right)$ production increased at higher doses in cases of single and joint applications. With the increase in their concentrations, the activities of antioxidant enzymes such as superoxide dismutase (SOD), peroxidase (POD), and catalase (CAT) were found to be pronouncedly enhanced as compared to control. Ultrastructural alterations in mesophyll cells of maize leaf were mostly found in chloroplast and nucleus. The present study revealed that short-term exposure of maize
\end{abstract}

*e-mail: shjzhu@zju.edu.cn

**e-mail: mkdaud@yahoo.com 
seedlings to pesticides (LC and EB) caused less stressful effects on maize due to the presence of active antioxidative metabolism, which indicates the resistant nature of maize toward these pesticides.

Keywords: Emamectin benzoate, lambda cyhalotherin, reactive oxygen species, antioxidative defense, electron microscopy

\section{Introduction}

Pesticides are a class of xenobiotic compounds that have been used to destroy or repel unwanted animals, insects and plants (weeds) for several decades. They consist of a wide range of compounds, namely herbicides, nematicides, insecticides, molluscicides, etc. In developing countries, they are used extensively and their application is expected to increase in coming years. All classes of pesticides are of great global concern because they not only pollute our biosphere but also cause adverse effects on human health as well as crop yields [1]. They are classificed according to their hazardous effects, and all of them either fall into the category of highly $(34.2 \%)$ or moderately $(35.0 \%)$ poisonous [2]. In human beings, they have significant chronic health effects, including cancer, neurological effects, diabetes, respiratory diseases, fetal diseases, and genetic disorders. These health effects are different depending on the degree and type of exposure [3] to various pesticides. In plants, the use of pesticides has direct or indirect effects on normal physiological and biochemical functions of plants. Their excessive use causes various toxicity symptoms in plants, leading to reduced seed germination, shoot length, root length and biomass, chlorosis, necrosis, retarded growth and photosynthetic efficiency $[4,5]$. As a result, plants abnormally develop, their growth is inhibited and ultimately their survival is threatened. Previous research has shown that pesticide-induced abnormal growth and development in plants is mostly due to their inability to take up the essential micro nutrients [6] present in the growth media as well as their modes of action that may interfere with photosynthesis, thus causing chlorophyll degradation [7-10].

Oxidative stress has core importance in both aboitic and biotic stresses. It is produced when there is a critical disturbance between the production of antioxidative defense and reactive oxygen species (ROS). After application, pesticides pass through the degradation stage by numerous physiochemical reactions such as autolysis, photolysis, rearrangement, and inactivation upon binding to soil and macromolecules, and may cause the generation of reactive oxygen species (ROS) [11]. ROS are highly reactive molecules and cause profound demage to various macromolecules of cells, that is lipids, proteins and nucleic acids [12]. They are such as superoxide $\left(\mathrm{O}^{2 \cdot-}\right)$, hydrogen peroxide $\left(\mathrm{H}_{2} \mathrm{O}_{2}\right)$ and hydroxyl radical $\left(\mathrm{OH}^{-}\right)$. Higher production of ROS significantly degrades polyunsaturated lipids, resulting in the formation of malodialdehyde (MDA), which represents the degree of membrane lipid peroxidation of the cells [13]. The MDA is a three-carbon dialdehyde molecule that is formed by oxidation of fatty acid present in the cell membrane in response to abiotic stress [14].

Like against any other environmental stress, plants also need to alleviate the negative effects of pesticides and to protect cellular organelles from pesticideinduced oxidative damage. They present either a detoxification or a biotransformation strategy. In to detoxify the pesticides, plant cells have to activate a complex antioxidative defense mechanism comprised of various ROS-scavenging enzymatic antioxidants such as superoxide dismutase (SOD), peroxidase (POD) and catalase (CAT), along with non-enzymatic antioxidants such as glutathione, vitamin $\mathrm{C}$ and vitamin E, which play a significant role in maintaining the ROS level within limits [15]. SOD is part of a group of metalloenzymes that catalyze the conversion of reactive $\mathrm{O}^{2-}$ to produce $\mathrm{H}_{2} \mathrm{O}_{2}$, and is also the first defense against environmental stress. $\mathrm{H}_{2} \mathrm{O}_{2}$ can be subsequently detoxified by two types of enzymes - CAT and POD - and is reduced to water by ascorbate peroxidase (APX), utilizing ascorbate (as a specific electron donor). Utilizing their biotransformation strategy, plants first convert pesticides into a less-toxic product by oxidation, reduction and hydrolysis, then conjugate pesticide metabolite through glutathione-S transferase and uridine diphosphate-glycosyltransferase into sugar, amino acid or glutathione, and finally transport these metabolites from plants' cytosol to the vacuoles and apoplasts [16].

In our present experiment we used two pesticides, namely Lambda cyhalotherin (LC) and emamectin benzoate (EB), which have broader uses against insects of various summer and winter crops. Single and joint applications of these two pesticides (LC and EB) cause several toxicity symptoms in plants at various functional levels, including physiological, ultramorphological and biochemical. Physiological disturbances such as changes in growth, water transport, biomass, length of seedlings, alteration in the antioxidative enzyme, disturbances in the metabolic function of cell organelles, and production of ROS have been reported [17]. Ultrastructural studies have revealed that pesticides had adverse effects on maize leaf. Alterations in the structure of the thylakoid in chloroplasts, increased disruption in the nucleous structure, an increase in the number of plastoglubli and highly inflated vacuoles in Euptorium adenophorum have been reported by Liu et al. [18].

In this study, we tested maize seedling responses toward single and joint stress of pesticides (lambda 
cyhalotherin and emamectin benzoate) using various physiological, biochemical and ultramorphological responses of leaves. Maize is known as the "king of grain crops", having a number of uses such as ethanol production, food and feed for animals, remediation of varios toxic metals, etc. [19]. Maize is the third largest cultivated crop in Pakistan, covering 896,000 hectares after wheat and rice. Both Punjab and Khyber Pakhtunkhwa account for $98 \%$ of the area under maize cultivation. Keeping in view the drastic effects of pesticide usage in plants, we designed the present experiment using various physiological, biochemical and ultramorphological approaches to gain comprehensive knowledge of the responses of maize seedlings under single and joint exposure of pesticides, i.e., LC and EB.

\section{Materials and Methods}

\section{Plant Culture Conditions}

Maize (cv Azam) was used in the present experiment. Uniform-sized seeds were surface sterilized using $70 \%$ ethanol for $3 \mathrm{~min}$ and then rinsed with distilled water 2 to 3 times. Sterilized seeds were kept at room temperature to dry them. The next day they were sown in sand culture supplemented with $20 \mathrm{ml}$ nutrient solution having different concentrations of two pesticide solutions (EB and LC) on their own and in combination with concentrations in $\mathrm{mg} / \mathrm{L} / 1 \mathrm{Kg}$ of sterilized sand [i.e., 0 (control), $\mathrm{EB}_{100}, \mathrm{~EB}_{300}, \mathrm{~EB}_{600 \mathrm{ppm}}, \mathrm{LC}_{100}, \mathrm{LC}_{500}$, $\mathrm{LC}_{800 \mathrm{mg} / \mathrm{L}}$, and Joint $\left.\left(\mathrm{EB}_{300}+\mathrm{LC}_{500 \mathrm{mg} / \mathrm{L}}\right)\right]$ for 12 days under controlled growth conditions. Seeds were kept in complete darkness for the first three days and thereafter 14:10 hours photoperiod under white fluorescent light was provided for the next 9 days at a temperature of $28.00 \pm 2.00^{\circ} \mathrm{C}$ culture temperatures and $60 \%$ relative humidity. After three days, pots were nourished on a daily basis with $10 \mathrm{ml}$ Hoagland's nutrient solution per pot with $\mathrm{pH}$ of 5-6. The pesticide solution, $20 \mathrm{ml}$ per pot, was refreshed on the $10^{\text {th }}$ day, followed by harvesting on the $12^{\text {th }}$ day of sowing. The next day, seedling roots were thoroughly washed with $20 \mathrm{mM}$ EDTA$\mathrm{Na}_{2}$ for $15 \mathrm{~min}$ in order to remove adherent metals. Then, seedlings were divided into roots, stems, and leaves for physiological, biochemical, and ultrastructural studies.

\section{Measuring Physiological Parameters}

The number of germinated seeds were examined after every $12 \mathrm{~h}$ for 4 days. At the end of the experiment various physiological parameters such as length (root, stem and leaf), fresh and dry biomasses (root, stem and leaf) were measured in centimeter $(\mathrm{cm})$ and grams respectively. To determine the dry biomass, all parts of the seedlings were oven-dried at $80^{\circ} \mathrm{C}$ for 72 hours.

\section{Measurements of Photosynthetic Pigments and Ion Concentrations}

A dried plant sample $(25 \mathrm{mg})$ was taken in a test tube and magnesium oxide (MgO) $(25 \mathrm{mg}$ ) was added to neutralize plant acid and prevent the formation of pheophytin. Then methanol $(5 \mathrm{ml})$ was added and the sample was homogenized with a shaker for $2 \mathrm{~h}$. The turbid pigment extract was transferred to a $5 \mathrm{ml}$ graduated centrifuge tube and centrifuged for 5 minutes at $4000 \mathrm{rpm}$ at room temperature. After centrifuging, the supernatant was transferred with a pippet to a $1-\mathrm{cm}$ path length cuvette and absorbance readings were taken against a solvent blank in a UV-VIS spectrophotometer at three different wavelengths: $666 \mathrm{~nm}, 653 \mathrm{~nm}$ and $470 \mathrm{~nm}$. Chlorophyll " $a$ ", " $b$ " and total carotenoids were calculated according to equations given by Lichtenthaler and Wellburn [20]:

$$
\begin{gathered}
\mathrm{C}_{\mathrm{a}}=15.65 \mathrm{~A}_{666}-7.340 \mathrm{~A}_{653} \\
\mathrm{C}_{\mathrm{b}}=27.05 \mathrm{~A}_{653}-11.21 \mathrm{~A}_{666} \\
\mathrm{C}_{\mathrm{x}+\mathrm{c}}=\left(1000 \mathrm{~A}_{470}-2.860 \mathrm{C}_{\mathrm{a}}-129.2 \mathrm{C}_{\mathrm{b}}\right) / 245
\end{gathered}
$$

The modified method of Awan and Salim [21] was used to determine ions. Oven-dried leaf materials were ground to fine powder for ion analysis using a flame photometer. Twenty-five mg dry material of both roots and leaves were continuously digested with the mixture of hydrogen peroxide and sulphuric acid at a ratio of $2: 1(\mathrm{v} / \mathrm{v})$ in a $50 \mathrm{ml}$ beaker with continuous heating until small oily drops were obtained. After this, $25 \mathrm{ml}$ of distilled water was added to each sample. Beakers were put in a shaker in order to digest the materials completely, followed by filtration. For specific ion analysis, $100 \mathrm{ppm}$ concentration standard was prepared. After preliminary standardization of the flame photometer with standard solutions, the concentrations of $\mathrm{Na}^{+}, \mathrm{K}^{+}$and $\mathrm{Ca}^{+2}$ were determined in all plant samples.

\section{Determination of Lipid Peroxidation and Hydrogen Peroxide}

Approximately $0.8 \mathrm{~g}$ leaf material was taken from both pesticide-treated and control maize seedlings and was used for determining lipid peroxide and hydrogen peroxide. The sample crushed in $8.0 \mathrm{ml}$ of trichloroacetic acid (TCA) $(0.1 \%, \mathrm{w} / \mathrm{v})$ at ice conditions and the homogenate was centrifuged at $14,000 \mathrm{~g}$ for $20 \mathrm{~min}$. Lipid peroxidation was estimated in terms of malondialdehyde (MDA) contents and was determined as 2-thiobarbituric acid (TBA) reactive substances following the method of Daud et al. [22]. For determining hydrogen peroxide $\left(\mathrm{H}_{2} \mathrm{O}_{2}\right)$ content we used the protocol of Velikova et al. [23]. The reaction mixture of $4 \mathrm{~mL}$ contained $1 \mathrm{ml}$ supernatant, $1 \mathrm{ml}$ phosphate 
buffer solution, and $2 \mathrm{ml}$ of $1 \mathrm{M}$ potassium iodide (KI). The absorbance was measured at $390 \mathrm{~nm} . \mathrm{H}_{2} \mathrm{O}_{2}$ content was determined using an extinction coefficient of $0.28 \mu \mathrm{Mcm}-1$ and expressed as $\mu \mathrm{mol} \mathrm{g}-1 \mathrm{FW}$.

\section{Measurement of Total Soluble Protein (TSP), Total Soluble Sugar (TSS) and Proline}

In order to determine the total soluble proteins, $0.8 \mathrm{~g}$ leaf sample was homogenized in $8 \mathrm{ml}$ of $50 \mathrm{mM}$ potassium phosphate buffer $(\mathrm{PBS})(\mathrm{pH}=7.8)$ under chilled conditions. The crude extract was centrifuged at $14,000 \mathrm{rpm}$ for $15 \mathrm{~min}$ at $4^{\circ} \mathrm{C}$ and the supernatant was used for determining total soluble protein using the method of Bradford [24] using bovine albumin as a standard. Total soluble sugar in leaves was estimated by the method of Dey [25]. Briefly, $0.5 \mathrm{~g}$ leaves were crushed twice with hot $90 \%$ ethanol. The ethanol extracts were then combined. The final volume of the pooled extract was made to $25 \mathrm{ml}$ with double-distilled water. A suitable aliquot was taken from the extract and $1 \mathrm{ml} \mathrm{5 \%}$ phenol and $5 \mathrm{ml}$ concentrated sulphuric acid were added. Final volume of this solution was made up to $10 \mathrm{ml}$ with the addition of double-distilled water. Absorbance of extract was measured at $485 \mathrm{~nm}$ using a UV-Vis spectrophotometer. Proline concentration in treated and untreated leaves of maize seedlings was determined spectrophotometrically by the method of Bates et al. [26].

\section{Determination of Antioxidant Enzymes Activities}

In the present experiment, we also calculated various ROS-scavenging enzymes using the previously published protocols. Leaves were homogenized in ice-cold $50 \mathrm{mM}$ sodium phosphate buffer ( $\mathrm{pH}$ 7.8) containing $2 \mathrm{mM}$ ethylenediamine-tetra acetic acid (EDTA) and 1\% (w/v) polyvinyl-polypyrrolidon (PVP). The crude enzyme extract was twice centrifuged at $12,000 \mathrm{rpm}$ for $15 \mathrm{~min}$ at $4^{\circ} \mathrm{C}$ and the supernatants were analyzed for enzyme activities.

Superoxide dismutase (SOD) (EC1.15.1.1) activity was determined according to Zhang et al. [27] following the inhibition of photochemical reduction due to nitro blue tetrazolium (NBT). The total reaction mixture consisted of $50 \mathrm{mM}$ potassium phosphate buffer $(\mathrm{pH}=7.8), 13 \mathrm{mM}$ methionine, $75 \mathrm{mM}$ NBT, $2 \mathrm{mM}$ riboflavin, $0.1 \mathrm{mM}$ EDTA-Na $\mathrm{Na}_{2}$ and $100 \mu \mathrm{l}$ of enzyme extract in a $3 \mathrm{ml}$ volume. One unit of SOD activity was measured as the amount of enzyme required to cause $50 \%$ inhibition of the NBT reduction measured at $560 \mathrm{~nm}$.

Peroxidase (POD, EC1.11.1.7) activity was assayed as described by Ali et al. [28]. Briefly, the reactant mixture contained $50 \mathrm{mM}$ potassium phosphate buffer $(\mathrm{pH}=7.8), 1.0 \%$ guaiacol, $0.4 \% \mathrm{H}_{2} \mathrm{O}_{2}$ and $100 \mu \mathrm{l}$ enzyme extract. Variation due to guaiacol in absorbance was measured at $470 \mathrm{~nm}$. Catalase (CAT) (EC 1.11.1.6) activity was measured according to Daud et. al. [22]. Briefly, the disappearance of $\mathrm{H}_{2} \mathrm{O}_{2}$ was monitored by measuring the decrease in absorbance at $240 \mathrm{~nm}$ $\left(E=0.036 \mathrm{mM}^{-1} \mathrm{~cm}^{-1}\right)$ of a reaction mixture consisting of $25 \mathrm{mM}$ potassium phosphate buffer ( $\mathrm{pH}$ 7.8), $10 \mathrm{mMH}_{2} \mathrm{O}_{2}$, and enzyme extract.

\section{Transmission Electron Microscopy}

Transmission electron microscopy of leaf mesophyl cells was performed by using the protocol of Daud et al. [29]. Leaf fragments without veins (approximately $1 \mathrm{~mm}^{2}$ ) of randomly selected plants were fixed overnight in $2.5 \%$ glutaraldehyde (v/v) in $0.1 \mathrm{M}$ PBS (sodium phosphate buffer, $\mathrm{pH}$ 7.4) and washed three times with the same PBS solution. The samples were post fixed in $1 \% \mathrm{OsO}_{4}$ (osmium (VIII) oxide) for $1 \mathrm{hr}$, then washed three times in $0.1 \mathrm{M}$ PBS ( $\mathrm{pH} 7.4$ ) with $10 \mathrm{~min}$ intervals between each washing. Then, with a 15-20 min interval they were dehydrated in a graded ethanol series $(50,60,70,80,90,95$, and $100 \%)$ and finally by absolute acetone for $20 \mathrm{~min}$. The samples were then infiltrated and embedded in Spurr's resin overnight. After heating the specimens at $70^{\circ} \mathrm{C}$ for $9 \mathrm{~h}$, the ultrathin sections $(80 \mathrm{~nm})$ were prepared and mounted on copper grids for viewing in the transmission electron microscope (JEOL TEM-1230EX) at an accelerating voltage of $60.0 \mathrm{kV}$.

\section{Statistical Analyses}

The data were subjected to one-way analysis of variance (ANOVA) using STATIX9 for statistical significance at $P<0.05$. All the results were the mean $\pm \mathrm{SE}$ of three replicates results. Means were separated by least significant difference (LSD) test at 5\% significance level.

\section{Results}

Effects of Pesticide Application on Physiological Parameters

\section{Effects on Root, Shoot and Leaf Length}

Table 1 shows mean data of germination and length (root, stem and leaf) of maize seedlings under single and joint toxicity of pesticides (LC and EB). Low levels of pesticides increased the mean values of these parameters. However, they significantly decreased with the increase in the concentrations of these pesticides. The joint application of both pesticides also pronouncedly reduced the mean values of these parameters. The lowest germination percentage was noted at higher concentrations of both pesticides, i.e., 35.80 and $38.36 \%$ at $800 \mathrm{mg} / \mathrm{L} \mathrm{LC}$ and $600 \mathrm{mg} / \mathrm{L} \mathrm{EB}$, respectively. Furthermore, the highest reduction was found in leaf length of both pesticides $\mathrm{L}_{800}(52.92 \%)$ 
Table 1. Seed germination and seedling lengths (root, stem and leaves) of maize under single and joint toxicity of pesticides; values are means \pm SE of three replications.

\begin{tabular}{|c|c|c|c|c|}
\hline \multirow{2}{*}{ Treatment $(\mathrm{mg} / \mathrm{L})$} & \multirow{2}{*}{ Germination (\%) } & \multicolumn{3}{|c|}{ Length (cm/plant) } \\
\cline { 3 - 5 } & & Root & Stem & $23.60 \pm 1.36^{\mathrm{a}}$ \\
\hline $\mathrm{CK}$ & $100 \pm 0.29^{\mathrm{b}}$ & $17.90 \pm 1.87^{\mathrm{b}}$ & $6.39 \pm 0.13^{\mathrm{a}}$ & $25.02 \pm 0.56^{\mathrm{a}}$ \\
\hline $\mathrm{LC}_{100}$ & $117.67 \pm 0.05^{\mathrm{a}}$ & $22.21 \pm 0.96^{\mathrm{a}}$ & $6.62 \pm 0.29^{\mathrm{a}}$ & $17.28 \pm 1.21^{\mathrm{b}}$ \\
\hline $\mathrm{LC}_{500}$ & $47.12 \pm 0.13^{\mathrm{c}}$ & $13.33 \pm 0.30^{\mathrm{c}}$ & $4.12 \pm 0.11^{\mathrm{b}}$ & $11.11 \pm 0.62^{\mathrm{c}}$ \\
\hline $\mathrm{LC}_{800}$ & $35.80 \pm 0.07^{\mathrm{d}}$ & $9.41 \pm 0.31^{\mathrm{d}}$ & $2.67 \pm 0.46^{\mathrm{c}}$ & $25.04 \pm 0.19^{\mathrm{a}}$ \\
\hline $\mathrm{EB}_{100}$ & $115.71 \pm 0.15^{\mathrm{a}}$ & $19.53 \pm 0.43^{\mathrm{a}}$ & $6.60 \pm 0.17^{\mathrm{a}}$ & $15.34 \pm 1.81^{\mathrm{b}}$ \\
\hline $\mathrm{EB}_{300}$ & $52.87 \pm 0.44^{\mathrm{c}}$ & $14.72 \pm 0.99^{\mathrm{b}}$ & $4.26 \pm 0.18^{\mathrm{b}}$ & $11.14 \pm 0.43^{\mathrm{c}}$ \\
\hline $\mathrm{EB}_{600}$ & $38.36 \pm 0.18^{\mathrm{d}}$ & $10.72 \pm 0.53^{\mathrm{c}}$ & $3.17 \pm 0.25^{\mathrm{c}}$ & $13.36 \pm 0.47^{\mathrm{b}}$ \\
\hline $\mathrm{LC}_{500}+\mathrm{EB}_{300}$ & $63.44 \pm 0.08^{\mathrm{b}}$ & $12.80 \pm 0.99^{\mathrm{a}}$ & $3.21 \pm 0.28^{\mathrm{b}}$ & \\
\hline
\end{tabular}

CK: Control, LC: Lambda Cyhalotherin, EB: Emamectin Benzoate

and $\mathrm{E}_{600}(52.79 \%)$, followed by root length of maize seedlings at $\mathrm{LC}_{800}(47.43 \%)$ and $\mathrm{EB}_{600}(40.11 \%)$. The joint stress significantly reduced the lengths in the order of leaf $>$ root $>$ stem.

\section{Effect on Biomass (Fresh and Dry Weight)}

The mean values of fresh and dry biomass of root, stem and leaf of maize cultivars along with their relative increase or decrease are presented in (Table 2). The tabulated data shows that fresh and dry biomasses of the root, shoot and leaf decreased at high concentrations of pesticides $\left(\mathrm{LC}_{800 \mathrm{mg} / \mathrm{L}}\right.$ and $\left.\mathrm{EB}_{600 \mathrm{mg} / \mathrm{L}}\right)$ as compared to control. However, comparing seedlings treated with both pesticides with control at lower reduction in mass was observed while the percent inhibitory rates increased at $\mathrm{LC}_{100}$ and $\mathrm{EB}_{100 \mathrm{mg} / \mathrm{L}}$ relative to control samples.
Effect of Pesticide Application on Biochemical Parameters (i.e., Photosynthetic Pigments and Ionic Concentrations, Oxidative Metabolism)

Mean data for photosynthetic pigment and ionic concentrations shows variable responses (Table 3). As a whole, statistically significant inhibition $(\mathrm{P}<0.05)$ was found in chlorophyll $a$ and $b$, carotenoids and ionic content relative to control samples. At higher concentrations $\mathrm{LC}_{800}, \mathrm{~EB}_{600}$ and joint stress of both pesticides, the mean value of chlorophyll $a$ was reduced from 7.08 to 4.32 and 3.78 , respectively. In the case of chlorophyll $b$ and carotenoids, a similar inhibition pattern was observed.

Pesticide stress affected the ionic contents of maize seedlings. $\mathrm{Ca}^{++}$and $\mathrm{K}^{+}$content increased by $20.67 \%$ $\left(\mathrm{LC}_{800}\right.$ and $\left.\mathrm{EB}_{600}\right)$ and $43.25 \%$ at $\mathrm{LC}_{800}$ and $30.81 \%$ at $\mathrm{EB}_{600}$ respectively. At joint stress, $\mathrm{Ca}^{++}$and $\mathrm{K}^{+}$were $11.97 \%$ and $42.71 \%$ respectively over their respective

Table 2. Biomass of roots, stems and leaves of maize under single and joint toxicity of pesticides; values are the means $\pm \mathrm{SE}$ of three replications.

\begin{tabular}{|c|c|c|c|c|c|c|}
\hline \multirow{2}{*}{$\begin{array}{c}\text { Treatment } \\
(\mathrm{mg} / \mathrm{L})\end{array}$} & \multicolumn{3}{|c|}{ Fresh Biomass (gm/plant) } & \multicolumn{3}{c|}{ Dry Biomass (gm/plant) } \\
\cline { 2 - 7 } & Root & Stem & Leaf & Root & Stem & Leaf \\
\hline $\mathrm{CK}$ & $1.30 \pm 0.03^{\mathrm{a}}$ & $1.01 \pm 0.00^{\mathrm{a}}$ & $0.78 \pm 0.03^{\mathrm{b}}$ & $0.06 \pm 0.00^{\mathrm{ab}}$ & $0.07 \pm 0.00^{\mathrm{a}}$ & $0.07 \pm 0.00^{\mathrm{ab}}$ \\
\hline $\mathrm{LC}_{100}$ & $1.35 \pm 0.10^{\mathrm{a}}$ & $1.07 \pm 0.00^{\mathrm{a}}$ & $1.11 \pm 0.19^{\mathrm{a}}$ & $0.08 \pm 0.00^{\mathrm{a}}$ & $0.07 \pm 0.00^{\mathrm{a}}$ & $0.08 \pm 0.00^{\mathrm{a}}$ \\
\hline $\mathrm{LC}_{500}$ & $1.06 \pm 0.04^{\mathrm{b}}$ & $0.82 \pm 0.11^{\mathrm{b}}$ & $0.62 \pm 0.07^{\mathrm{b}}$ & $0.05 \pm 0.00^{\mathrm{b}}$ & $0.05 \pm 0.00^{\mathrm{b}}$ & $0.05 \pm 0.00^{\mathrm{b}}$ \\
\hline $\mathrm{LC}_{800}$ & $0.62 \pm 0.16^{\mathrm{c}}$ & $0.43 \pm 0.04^{\mathrm{c}}$ & $0.36 \pm 0.09^{\mathrm{c}}$ & $0.01 \pm 0.00^{\mathrm{c}}$ & $0.02 \pm 0.00^{\mathrm{c}}$ & $0.03 \pm 0.00^{\mathrm{c}}$ \\
\hline $\mathrm{EB}_{100}$ & $1.33 \pm 0.10^{\mathrm{a}}$ & $1.04 \pm 0.00^{\mathrm{a}}$ & $0.98 \pm 0.06^{\mathrm{a}}$ & $0.07 \pm 0.00^{\mathrm{a}}$ & $0.07 \pm 0.00^{\mathrm{a}}$ & $0.07 \pm 0.00^{\mathrm{a}}$ \\
\hline $\mathrm{EB}_{300}$ & $1.28 \pm 0.14^{\mathrm{a}}$ & $0.97 \pm 0.04^{\mathrm{a}}$ & $0.57 \pm 0.06^{\mathrm{c}}$ & $0.05 \pm 0.00^{\mathrm{b}}$ & $0.06 \pm 0.00^{\mathrm{a}}$ & $0.06 \pm 0.00^{\mathrm{b}}$ \\
\hline $\mathrm{EB}_{600}$ & $0.57 \pm 0.14^{\mathrm{b}}$ & $0.55 \pm 0.05^{\mathrm{b}}$ & $0.40 \pm 0.04^{\mathrm{c}}$ & $0.02 \pm 0.00^{\mathrm{c}}$ & $0.03 \pm 0.00^{\mathrm{b}}$ & $0.04 \pm 0.00^{\mathrm{c}}$ \\
\hline $\mathrm{LC}_{500}+\mathrm{EB}_{300}$ & $1.06 \pm 0.13^{\mathrm{b}}$ & $0.62 \pm 0.62^{\mathrm{b}}$ & $0.55 \pm 0.05^{\mathrm{b}}$ & $0.05 \pm 0.00^{\mathrm{a}}$ & $0.05 \pm 0.00^{\mathrm{b}}$ & $0.05 \pm 0.00^{\mathrm{b}}$ \\
\hline
\end{tabular}

CK: Control, LC: Lambda Cyhalotherin, EB: Emamectin Benzoate. 
Table 3. Photosynthetic pigments and ion analysis of maize leaves under single and joint toxicity of pesticides; values are the means \pm SE of three replications.

\begin{tabular}{|c|c|c|c|c|c|c|}
\hline \multirow{2}{*}{$\begin{array}{c}\text { Treatment } \\
(\mathrm{mg} / \mathrm{L})\end{array}$} & \multicolumn{3}{|c|}{ Chlorophyll (mg/g DW) } & \multicolumn{3}{c|}{ Ions analysis (mg/g DW) } \\
\cline { 2 - 7 } & $\mathrm{Chl} a$ & $\mathrm{Chl} b$ & Carotenoids & $\mathrm{Na}^{1+}$ & $\mathrm{Ca}^{2+}$ & $\mathrm{K}^{1+}$ \\
\hline $\mathrm{CK}$ & $7.08 \pm 0.10^{\mathrm{b}}$ & $5.92 \pm 0.08^{\mathrm{b}}$ & $0.44 \pm 0.00^{\mathrm{ab}}$ & $38.33 \pm 1.20^{\mathrm{a}}$ & $30.66 \pm 0.66^{\mathrm{b}}$ & $61.66 \pm 0.66^{\mathrm{b}}$ \\
\hline $\mathrm{LC}_{100}$ & $8.19 \pm 0.07^{\mathrm{a}}$ & $7.33 \pm 0.73^{\mathrm{a}}$ & $0.48 \pm 0.02^{\mathrm{a}}$ & $40.66 \pm 1.45^{\mathrm{a}}$ & $32.66 \pm 1.85^{\mathrm{b}}$ & $82.33 \pm 1.20^{\mathrm{a}}$ \\
\hline $\mathrm{LC}_{500}$ & $6.39 \pm 0.11^{\mathrm{c}}$ & $5.59 \pm 0.13^{\mathrm{b}}$ & $0.40 \pm 0.01^{\mathrm{b}}$ & $25.00 \pm 1.15^{\mathrm{b}}$ & $34.00 \pm 0.57^{\mathrm{ab}}$ & $85.66 \pm 1.45^{\mathrm{a}}$ \\
\hline $\mathrm{LC}_{800}$ & $4.32 \pm 0.30^{\mathrm{d}}$ & $3.76 \pm 0.25^{\mathrm{c}}$ & $0.33 \pm 0.01^{\mathrm{c}}$ & $23.66 \pm 0.66^{\mathrm{b}}$ & $37.00 \pm 1.00^{\mathrm{a}}$ & $88.33 \pm 3.66^{\mathrm{a}}$ \\
\hline $\mathrm{EB}_{100}$ & $7.17 \pm 0.16^{\mathrm{a}}$ & $6.74 \pm 0.34^{\mathrm{a}}$ & $0.46 \pm 0.00^{\mathrm{a}}$ & $39.66 \pm 0.88^{\mathrm{a}}$ & $33.00 \pm 1.00^{\mathrm{bc}}$ & $61.87 \pm 1.73^{\mathrm{c}}$ \\
\hline $\mathrm{EB}_{300}$ & $5.38 \pm 0.45^{\mathrm{b}}$ & $5.97 \pm 0.53^{\mathrm{a}}$ & $0.39 \pm 0.01^{\mathrm{b}}$ & $33.66 \pm 1.76^{\mathrm{a}}$ & $34.66 \pm 0.66^{\mathrm{ab}}$ & $72.00 \pm 3.21^{\mathrm{b}}$ \\
\hline $\mathrm{EB}_{600}$ & $3.78 \pm 0.06^{\mathrm{c}}$ & $2.80 \pm 0.22^{\mathrm{b}}$ & $0.28 \pm 0.01^{\mathrm{c}}$ & $21.33 \pm 4.63^{\mathrm{b}}$ & $37.00 \pm 1.15^{\mathrm{a}}$ & $80.66 \pm 1.45^{\mathrm{a}}$ \\
\hline $\mathrm{LC}_{500}+\mathrm{EB}_{300}$ & $6.31 \pm 0.52^{\mathrm{a}}$ & $5.95 \pm 0.43^{\mathrm{a}}$ & $0.42 \pm 0.02^{\mathrm{a}}$ & $21.00 \pm 1.00^{\mathrm{b}}$ & $34.33 \pm 0.66^{\mathrm{a}}$ & $88.00 \pm 5.29^{\mathrm{a}}$ \\
\hline
\end{tabular}

CK: Control, LC: Lambda Cyhalotherin, EB: Emamectin Benzoate

control. Furthermore, $\mathrm{Na}^{+}$level increased up to $100 \mathrm{ppm}$ in both pesticide-treated plants, i.e., LC $(6.07 \%)$ and EB $(3.46 \%)$, and then declined the percentage at higher concentration of both pesticides, i.e., LC at $800 \mathrm{mg} / \mathrm{L}$ $(38.27 \%)$ and $\mathrm{EB}$ at $600 \mathrm{mg} / \mathrm{L}(44.35 \%)$, and recorded $45.21 \%$ at joint pesticidal stress (Table 3 ).

We also investigated the biomarkers of oxidative stress such as MDA and $\mathrm{H}_{2} \mathrm{O}_{2}$. Lipid peroxidation in terms of MDA contents in leaves of maize seedlings is shown in Table 4. MDA contents in leaves were lower than their respective controls. Lowest MDA contents (46.20\% and $19.31 \%$ over control were found at lower concentrations of both pesticides $\mathrm{LC}_{100}$ and $\mathrm{EB}_{100}$, respectively. As a whole, mean values of MDA contents were higher at $\mathrm{LC}_{800}(4.82 \%)$ over the other lower concentration of pesticides. However, the $\mathrm{H}_{2} \mathrm{O}_{2}$ contents in leaves almost increased with the increase in the levels of both types of pesticides. At $\mathrm{LC}_{500}, \mathrm{~EB}_{300}$ and joint $\left(\mathrm{LC}_{500}+\mathrm{EB}_{300}\right)$ level, mean data showed a $194.35 \%$, $157.25 \%$ and $140.31 \%$ increase over control.
Antioxidant enzyme (viz. SOD, POD, and CAT) activities in leaves of maize seedlings are shown in Table 4. As we increased the concentration of pesticidal stress, activities of these enzymes also increased. The maximum contents of SOD at $\mathrm{LC}_{800} \mathrm{mg} / \mathrm{L}$ and $\mathrm{EB}_{600} \mathrm{mg} / \mathrm{L}$ (370.68\%and 367.64\%) and POD (270.67\% and $237.96 \%$ ) were observed respectively. While at combined stress, the mean value of SOD and POD increased over the control. The increase of CAT activity was statistically significant at higher concentrations of both pesticides EB600 and LC800 mg/L, which were respectively 0.35 and $0.34 \mathrm{mM} / \mathrm{gFW}$ in comparison with control $(0.02 \mathrm{mM} / \mathrm{gFW})$.

\section{Effect of Pesticide Stress on Total Soluble Proteins (TSP), Total Soluble Sugar (TSS) and Proline}

The results for the effect of pesticide $(\mathrm{EB}, \mathrm{LC})$ on various stress biomarkers, i.e., TSP, TSS and proline

Table 4. MDA contents and antioxidative metabolism of maize seedling leaves under single and joint toxicity of pesticides; values are the means $\pm \mathrm{SE}$ of three replications.

\begin{tabular}{|c|c|c|c|c|c|}
\hline $\begin{array}{c}\text { Treatment } \\
(\mathrm{mg} / \mathrm{L})\end{array}$ & $\mathrm{MDA}(\mathrm{nmol} / \mathrm{gFW})$ & $\mathrm{H}_{2} \mathrm{O}_{2}(\mu \mathrm{M} / \mathrm{gFW})$ & $\mathrm{SOD}(\mathrm{U} / \mathrm{g} F W)$ & $\mathrm{POD}(\mathrm{mM} / \mathrm{gFW})$ & $\mathrm{CAT}(\mathrm{mM} / \mathrm{gFW})$ \\
\hline $\mathrm{CK}$ & $1.45 \pm 0.11^{\mathrm{a}}$ & $1.24 \pm 0.01^{\mathrm{b}}$ & $156.11 \pm 38.33^{\mathrm{d}}$ & $16.57 \pm 2.69^{\mathrm{b}}$ & $0.02 \pm 0.00^{\mathrm{c}}$ \\
\hline $\mathrm{LC}_{100}$ & $0.78 \pm 0.53^{\mathrm{a}}$ & $0.97 \pm 0.11^{\mathrm{b}}$ & $315.47 \pm 27.94^{\mathrm{c}}$ & $22.30 \pm 0.45^{\mathrm{b}}$ & $0.06 \pm 0.00^{\mathrm{b}}$ \\
\hline $\mathrm{LC}_{500}$ & $0.74 \pm 0.22^{\mathrm{a}}$ & $2.41 \pm 0.03^{\mathrm{a}}$ & $449.77 \pm 29.48^{\mathrm{b}}$ & $27.88 \pm 3.13^{\mathrm{b}}$ & $0.16 \pm 0.01^{\mathrm{a}}$ \\
\hline $\mathrm{LC}_{800}$ & $1.38 \pm 0.05^{\mathrm{a}}$ & $1.16 \pm 0.13^{\mathrm{b}}$ & $734.79 \pm 5.10^{\mathrm{a}}$ & $61.42 \pm 6.13^{\mathrm{a}}$ & $0.34 \pm 0.01^{\mathrm{a}}$ \\
\hline $\mathrm{EB}_{100}$ & $1.17 \pm 0.08^{\mathrm{ab}}$ & $1.10 \pm 0.42^{\mathrm{ab}}$ & $293.23 \pm 9.64^{\mathrm{c}}$ & $23.00 \pm 0.23^{\mathrm{b}}$ & $0.06 \pm 0.00^{\mathrm{c}}$ \\
\hline $\mathrm{EB}_{300}$ & $1.26 \pm 0.06^{\mathrm{ab}}$ & $1.95 \pm 0.31^{\mathrm{a}}$ & $485.18 \pm 24.35^{\mathrm{b}}$ & $24.11 \pm 0.61^{\mathrm{b}}$ & $0.23 \pm 0.01^{\mathrm{b}}$ \\
\hline $\mathrm{EB}_{600}$ & $0.72 \pm 0.39^{\mathrm{a}}$ & $0.85 \pm 0.05^{\mathrm{b}}$ & $730.04 \pm 4.89^{\mathrm{a}}$ & $56.00 \pm 2.77^{\mathrm{a}}$ & $0.35 \pm 5.05^{\mathrm{a}}$ \\
\hline $\mathrm{LC}_{500}+\mathrm{EB}_{300}$ & $0.21 \pm 0.10^{\mathrm{b}}$ & $1.74 \pm 0.03^{\mathrm{a}}$ & $547.58 \pm 42.55^{\mathrm{a}}$ & $23.42 \pm 0.43^{\mathrm{a}}$ & $0.21 \pm 0.02^{\mathrm{a}}$ \\
\hline
\end{tabular}

CK: Control, LC: Lambda Cyhalotherin, EB: Emamectin Benzoate, MDA: Malondialdehyde, $\mathrm{H}_{2} \mathrm{O}_{2}$ : Hydrogen peroxide, SOD:Superoxide dismutase, POD: Peroxidase, CAT:Catalase. 
Table 5. Metabolites of maize seedling leaves under single and joint toxicity of pesticides; values are the means \pm SE of three replications.

\begin{tabular}{|c|c|c|c|}
\hline Treatment $(\mathrm{mg} / \mathrm{L})$ & TSP $(\mathrm{mg} / \mathrm{g} \mathrm{F.W})$ & TSS $(\mathrm{mg} / \mathrm{g} \mathrm{F.W})$ & Proline (umol/gF.W) \\
\hline $\mathrm{CK}$ & $15.10 \pm 0.08^{\mathrm{d}}$ & $7.87 \pm 0.93^{\mathrm{c}}$ & $14.60 \pm 0.36^{\mathrm{a}}$ \\
\hline $\mathrm{LC}_{100}$ & $16.92 \pm 0.24^{\mathrm{c}}$ & $11.00 \pm 0.43^{\mathrm{b}}$ & $18.47 \pm 0.19^{\mathrm{c}}$ \\
\hline $\mathrm{LC}_{500}$ & $19.92 \pm 0.31^{\mathrm{b}}$ & $12.75 \pm 0.62^{\mathrm{b}}$ & $22.82 \pm 0.93^{\mathrm{b}}$ \\
\hline $\mathrm{LC}_{800}$ & $24.84 \pm 0.19^{\mathrm{a}}$ & $17.91 \pm 1.33^{\mathrm{a}}$ & $26.95 \pm 0.43^{\mathrm{a}}$ \\
\hline $\mathrm{EB}_{100}$ & $17.51 \pm 0.39^{\mathrm{c}}$ & $10.12 \pm 0.87^{\mathrm{bc}}$ & $19.58 \pm 0.48^{\mathrm{c}}$ \\
\hline $\mathrm{EB}_{300}$ & $19.42 \pm 0.57^{\mathrm{b}}$ & $12.41 \pm 0.46^{\mathrm{ab}}$ & $25.13 \pm 0.38^{\mathrm{b}}$ \\
\hline $\mathrm{EB}_{600}$ & $24.40 \pm 0.49^{\mathrm{a}}$ & $15.83 \pm 1.83^{\mathrm{a}}$ & $28.50 \pm 0.20^{\mathrm{a}}$ \\
\hline $\mathrm{LC}_{500}+\mathrm{EB}_{300}$ & $21.78 \pm 0.33^{\mathrm{b}}$ & $13.04 \pm 0.29^{\mathrm{a}}$ & $21.80 \pm 0.46^{\mathrm{b}}$ \\
\hline
\end{tabular}

CK: Control, LC: Lambda Cyhalotherin, EB: Emamectin Benzoate, TSP: Total Soluble Proteins, TSS: Total Soluble Sugars.
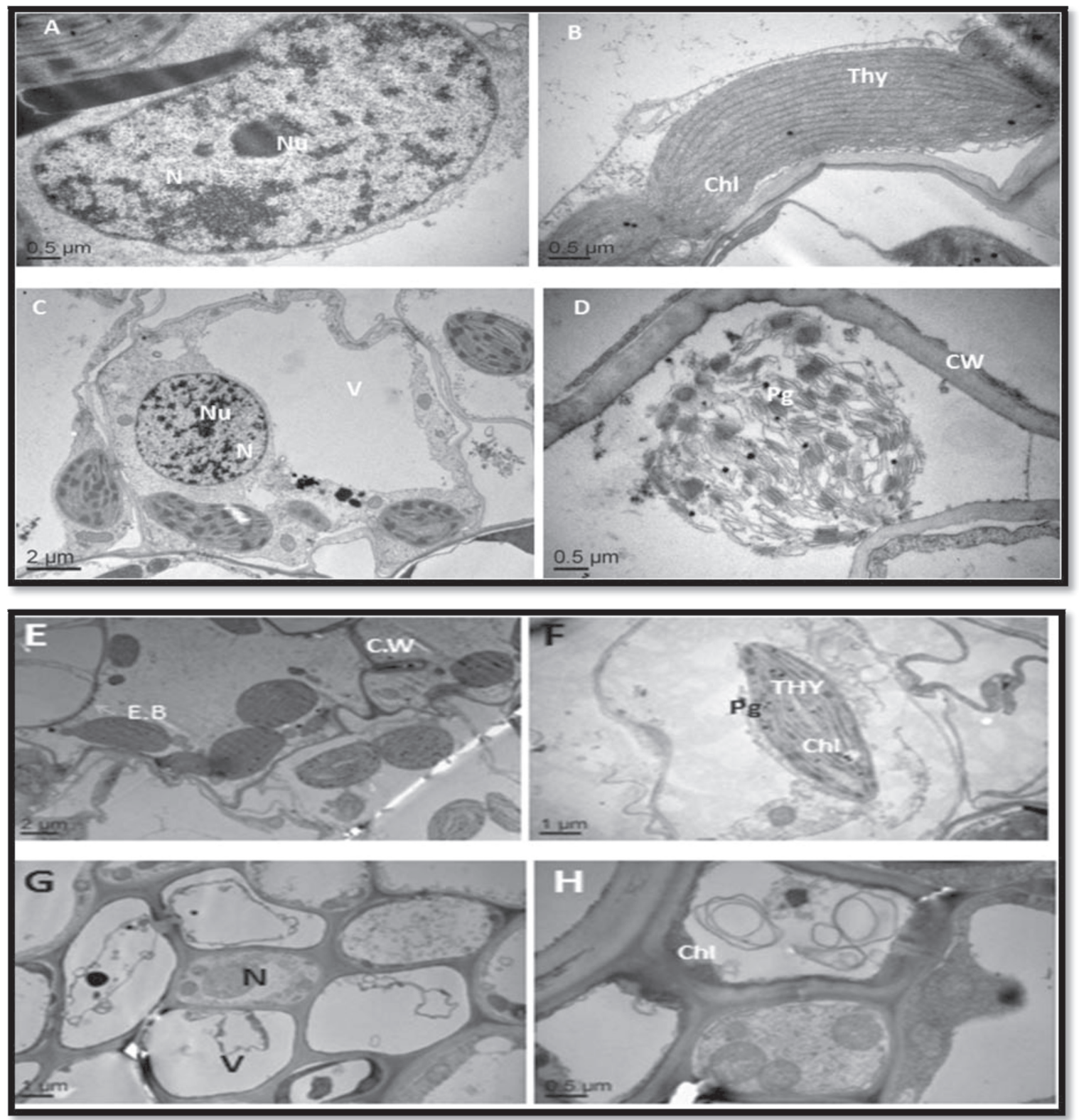

Fig. 1. Electron micrograhps of transmission $(\mathrm{A}-\mathrm{H})$ of maize leaf mesophyll cell in both pesticide non-stressed (A-B) and pesticidestressed conditions $\mathrm{L}_{800}(\mathrm{C}-\mathrm{D}), \mathrm{E}_{600}(\mathrm{E}-\mathrm{F}), \mathrm{J}_{(\mathrm{L} 500+\mathrm{E} 300)}(\mathrm{G}-\mathrm{H}) ; \mathrm{CW}=$ cell wall, Thy = thylakoids, $\mathrm{PG}=$ plastoglobuli, $\mathrm{N}=\mathrm{nucleus}, \mathrm{Nu}=$ nucleolus, $\mathrm{Chl}=$ chloroplast, $\mathrm{S}=$ starch granules, $\mathrm{LB}=$ lipid bodies. 
are shown in Table 5. Results indicate that total soluble protein (TSP) increased with increasing pesticide stress as compared to control. Higher mean values were recorded at $600_{\mathrm{mg} / \mathrm{L}}$ of $\mathrm{EB}$ and at $800_{\mathrm{mg} / \mathrm{L}}$ of LC $(24.40 \mathrm{mg} / \mathrm{g}, 24.84 \mathrm{mg} / \mathrm{g})$ respectively, while at combined stress $21.788 \mathrm{mg} / \mathrm{g}$ mean value was obtained for TSP.

An increase in total soluble sugar (TSS) was observed with increasing pesticide levels. Mean values recorded at high doses of pesticidal treated plants were 17.91 and $15.833 \mathrm{mg} / \mathrm{g} \mathrm{FW}$ as compared to control ( $7.875 \mathrm{mg} / \mathrm{gFW}$ ) at both $800 \mathrm{mg} / \mathrm{L} \mathrm{LC}$ and $600 \mathrm{mg} / \mathrm{L} \mathrm{EB}$ respectively. In the case of proline, maximum value was measured at higher concentrations, i.e., $26.95 \mathrm{mg} / \mathrm{g} \mathrm{FW}$ in LC $(800 \mathrm{mg} / \mathrm{L})$. Similarly in EB600 $\mathrm{mg} / \mathrm{L}$, proline amount was $28.50 \mathrm{mg} / \mathrm{g} \mathrm{FW}$ as compared to control (14.60 mg/g FW).
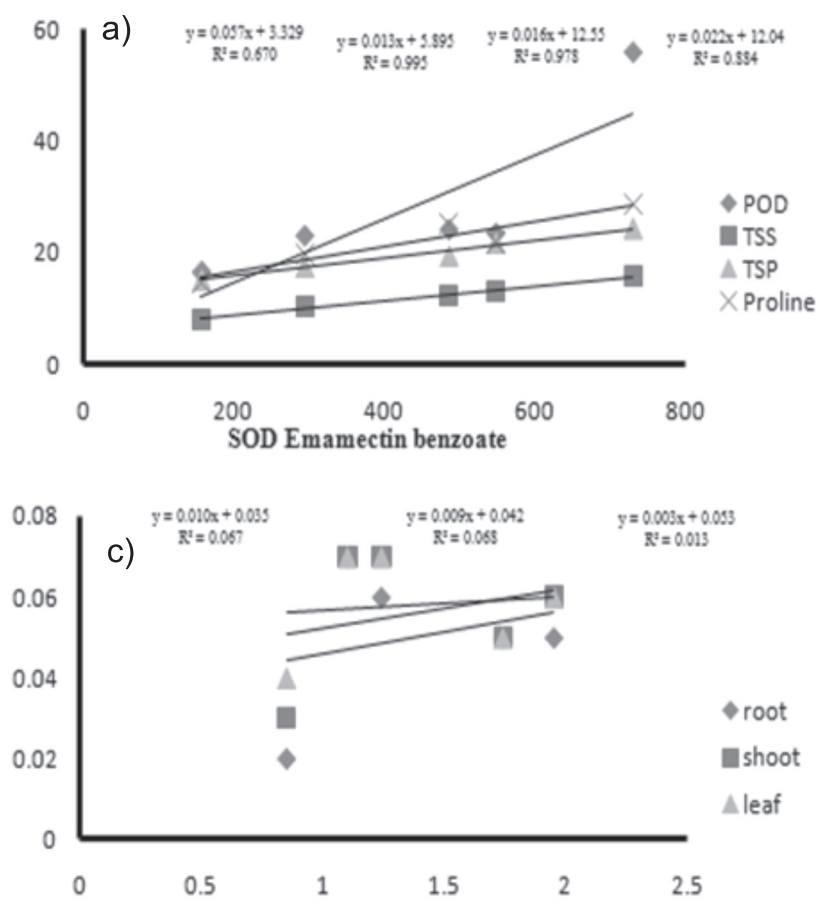

$\mathrm{H}_{2} \mathrm{O}_{2}$ Emamectin benzoate

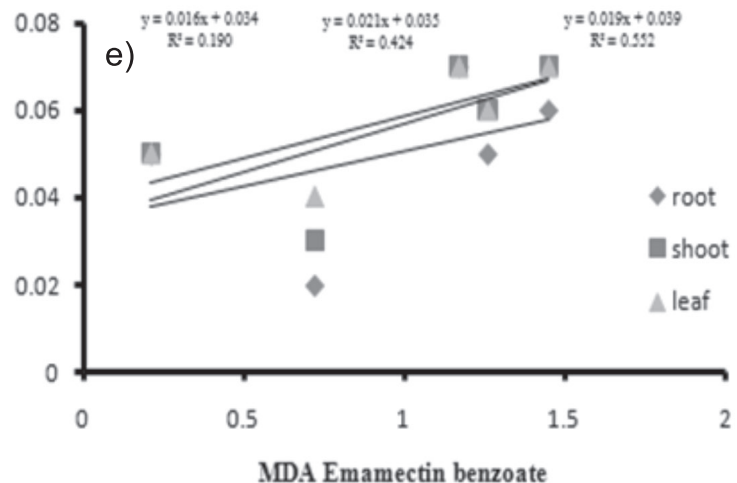

\section{Effect of Pesticides on Ultramorphology of Maize Leaves}

The ultramorphology of leaf mesophyll cells of maize seedlings was also studied using transmission electron microscopy. The leaf mesophyll cells' microstructural studies revealed evident alterations in both nucleous and chloroplast under pesticide stress (Fig. 1(A-H)). Under controlled conditions, the nucleus was of normal shaped and chloroplast possessed oval shape having well arranged thylakoids (Fig. 1(A-B)). However, the ultrastructure of pesticide $\left(\mathrm{LC}_{800}\right)$ treated the leaf's mesophyll cells are noticeably changed. The chloroplast ultrastructure deformed. Thylakoids were disturbed as well as vacuolar size and their number increased (Fig. 1(C-D)).

In $\mathrm{EB}_{600}$-treated cells (Fig. 1(E-F)), almost similar ultrastructural changes were observed in leaf
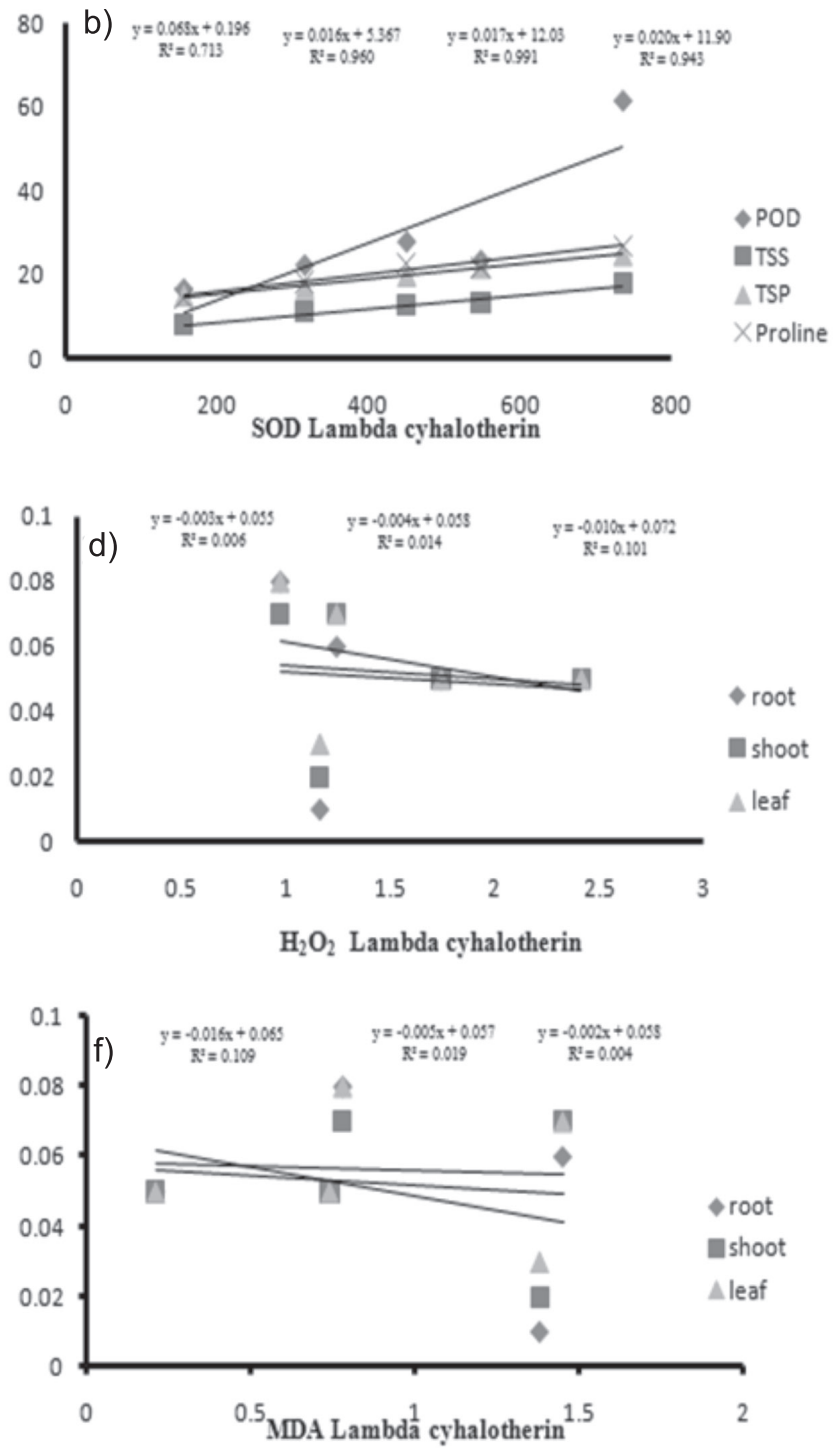

Fig. 2. Correlation among SOD, POD, TSP, TSS, PROLINE (a-b), $\mathrm{H}_{2} \mathrm{O}_{2}$, dry biomass (c-d), MDA dry biomass (e-f) of maize leaf in both pesticides lambda cyhalotherin and emamectin benzoate. 
mesophyll cells. An increase in the number of lipid bodies were observed. Chloroplasts were misshaped with little swollen and disrupted thylakoids. As a consequence of joint pesticide stress (i.e., $\mathrm{LC}_{500}+\mathrm{EB}_{300}$ ), (Fig. $1(\mathrm{G}-\mathrm{H})$ ), there were pragmatic alterations in cellular ultrastructure of the whole leaf as well as chloroplasts. Plasmolysis of the cell does occur and vacuolar size increased.

\section{Relationship Among Various Parameters of Maize Treated with Lambda Cyhalotherin and Emamectin Benzoate}

In Fig. 2 (a-b), SOD showed positive correlation with POD, TSS, TSP and proline of maize seedlings treated with pesticides Lambda cyhalotherin and Emamectin Benzoate. With the increase in SOD, POD, TSS, TSP and Proline of pesticide-treated seedlings increased with increased doses of LC and EB. Weak positive correlation was found between $\mathrm{H}_{2} \mathrm{O}_{2}$ and dry biomass (roots, shoots and leaves) of maize treated with EB (Fig. 2c). There was a weak negative correlation among the above-mentioned parameters with LC Fig. 2d). Furthermore, MDA showed positive correlation with dry biomass (roots, shoots, leaves) of maize treated with EB Fig. 2e). Negative correlation was found between MDA and dry biomass treated with LC Fig. 2f).

\section{Discussion}

Biotic and abiotic stresses of the environment result in severe damage to plant health, which finally lead to loss in both quality and quantity of the final product. Pesticidal stress also causes severe damage to plants, thus leading to poor crop production. Seed germination is a very complex and sensitive process involving various physiological activities at metabolic levels [30]. Its physiological and biochemical pathways are easily influenced by the presence of toxic elements, namely pesticides, in its germinating environment. Germination in the present experiment increased at lower doses of both LC and EB (i.e., 100 ppm). Similar was the case with various physiological parameters, i.e., biomass and shoot, root and leaf length, which were positively affected by low doses of LC and EB. However, the mean values of all these parameters decreased at higher doses. Similar to our results, Somatraken and Pratumna [31] in waxy corn also found a positive effect on physiological parameters at low concentrations and a negative effect at higher concentrations of various pesticides (heptachlore and endosulfan sulfate). The significant effect on seed germination and seedling vigour under pesticidal stress have also been reported in sunflower, pumpkin and water morning glory by Chouychai and Lee [32]. Chouychai [33] reported that lindaine and endosulfan in Brassica chinensis decreased root, shoot and leaf length and also decreased fresh and dry weight.
Calcium ion functions as a secondary messenger under stressful conditions [34]. $\mathrm{Na}^{+}$ions are responsible for maintaining membrane potential while $\mathrm{K}^{+}$ions are active and keeping osmotic balance. Their concentrations may significantly change under various environmental stresses [35]. In the present study, calcium and potassium ions increased, and a decrease in sodium ion was recorded with increasing pesticidal stress in maize seedlings. Due to chemical resemblance between the sodium and potassium ions, the uptake of potassium ion is increased.

Quantification of photosynthetic pigments ( $\mathrm{Chl} a$, $b$ and carotenoids) is an important assay to evaluate the plant responses to any environmental stress [36]. Changes in pigment concentrations in maize under various pesticide stress has also been previously demonstrated [37]. In the present study, photosynthetic pigments decreased at higher concentrations in cases of both pesticides. Similar results were reported by Shakir et al. [38] by the application of EB and LC on tomato. A decrease in pigment quantification with respect to increasing thiram concentrations were also found by [39] in a time-dependent manner. A decline in chlorophyll pigments could be due to the breakdown of thylakoids and chloroplast envelops [40] as revealed by evident changes in chloroplast ultrastructural alterations (Fig. 1A-H).

The application of higher levels of pesticides (LC, EB) have imposed stressful effects in leaves of treated maize seedlings as shown by the increase in MDA and $\mathrm{H}_{2} \mathrm{O}_{2}$ content. The present study also confirmed that when MDA contents (Table 4) increased in leaves of maize seedlings, the dry matter of roots, stem and leaf pronouncedly decreased (Table 2), and excessive leakage of electrolytes occured from maize seedlings (data not shown). Upregulation of MDA contents in the leaves of our experimental maize seedlings reveal that lipid perixdation of cellular membranes of leaf cell has been done and it indirectly conveys the message that oxidative damage has been caused in the leaves [41]. To combat such a situation, maize seedlings may have stimulated the free enzymes such as SOD, POD, and CAT. This is evident by overall increases in the mean values of these enzymes in the case of single and combined doses of both pesticides. Ferreira et al. [42] reported an increase in the activity of SOD in potato plants against oxidative damage cause by oxychloride fungicide applications. Moreover, upregulation in the activities of SOD, POD and CAT has been reported by various research groups using vigna radiata [43], tomato [44] and and Brassica campestris [45] as test plant species under various pesticidal stresses. Furthermore, Chris et al. [46] observed enhanced activity of SOD or POD in A. filiculoides exposed to pesticide monocrotophs. The upregulation of the activities of antioxidant enzymes and the presence of positive relationship of ROS with various celluar antioxidants reveal that the antioxidative mechanism of plants is mainly responsible to combat oxidative 
stress [47]. Similar results were reported by Nasrabadi et al. [48].

Previous studies have shown that any stressrelated stimuli could cause chloroplast dysfunction and photosynthetic damage [49, 50]. Resultantly, the synthesis of soluble sugar is negatively affected due to disturbance in the photosynthesis. Our present work clearly showed that total soluble sugar accumulated with an increasing concentration of pesticides, which highlights the adaptive strategy of maize seedlings to mitigate the ROS produced during pesticidal stress. Proline is a compatible solute and is an extensively studied molecule in plants under abiotic stress. The proteinogenic amino acid proline functions as an osmolyte, radical scavenger, electron sink, stabilizer of macromolecules, and a cell wall component [51]. Our results show that single and joint toxicity of both pesticides increased proline accumulation as compared to control. Similar results have been reported by Shakir et al. [52] and Nasrabadi and Dhumal [48] in tomato and brinjal under various pesticide stresses, respectively. Total soluble proteins (TSP) also plays a protective role during stress in many plant species such as rice, wheat, maize and various dicots. In the present study, it was noted that total soluble proteins accumulate in pesticide-treated plants. Similar findings were reported by Dragičević et al. [53] during the application of topramezone + dicamba on maize inbred line. Contrary to our results, TSP accumulation decreased with the higher concentration of pesticides as noted by Dubey et al. [54] and Rani et al. [55].

Alterations in the ultrastructures of leaf mesophyll cells were also observed in leaves of maize under single and joint stress of pesticides (Fig. 1A-H). The control plant had a normal leaf mesophyll cell with regularshaped nucleolus, vacuoles, and oval-shaped chloroplast having strongly-arranged and well aligned thylakoid. An appropriate number of nucleoli could also be observed in the electron micrograph (Fig. 1A-B). Electron micrographs show disorders in the normal structure of leaf mesophyll cells upon the application of both pesticides. They caused different kinds of abnormalities in various cell organelles such as the nucleous, vacuoles, and chloroplast (Figs.1 (C-H)). In pesticides-treated leaves, microstructural features such as disorganized chloroplast and dilated thylakoid membrane, and marked enhancement in a number of plastiglobuli were evident. In our study, the TEM analyses showed loosely arranged thylakoid lamellas in a leaf's cells with both pesticide (LC and EB) treatments. Our present findings are in line with the findings of other researchers. For example, Liu et al. [56] found that Rac-metolachlor and S-metolachlor had adverse effects on rice leaf cell ultrastructure. Liu et al. [18] investigated serious damage in chloroplast structure, and photosynthetic efficiency was reduced significantly by herbicide treatment (picloram). Aksoy and Dane [57] reported that leaves exposed to herbicides alter the chloroplast structure and decrease the photosynthesis process in maize cultivar.

\section{Conclusions}

In conclusion, both single and joint application of pesticides (LC and EB) adversely affected the physiological and photosynthetic pigments of maize seedlings. Both pesticides significantly influenced the metabolic parameters of maize seedling leaves. Moreover, the ultrastructures of leaf mesophyll cells were pronouncedly altered. Increases in the vacuolar size in the present study reveal that maize (Azam) might be helpful in accumulating more lambda cyhalotherin and emamectin benzoate in the dead parts of the cell. All types of parameters studied in the present experiment revealed that short-term exposure of maize seedlings to pesticides (LC and EB) caused less stressful effects on maize due to the presence of active antioxidative metabolism.

\section{Acknowledgments}

This project was jointly financed by Zhejiang University, China (973 Project of National Natural Science Foundation) and Kohat University of Science and Technology, Pakistan. We are grateful to Dr. Jun Ying Li of Zhejiang University in P.R. China for microscopic work.

\section{Conflict of Interest}

The authors declare no conflict of potential interest with respect to research, authorship and publication of this article.

\section{References}

1. IMRAN M.K., AQEEL M.S., ALAM S.C., NADEEM H.A., QADRI R. Use, contamination and exposure of pesticides in Pakistan: a review. Pak. J. Agr. Sci. 55, 2018.

2. DAMALAS C. A., KHAN M. Pesticide use in vegetable crops in Pakistan: Insights through an ordered probit model. Crop Prot. 99, 59, 2017.

3. RASTOGI S.K., TRIPATHI S., RAVISHANKER D. A study of neurologic symptoms on exposure to organophosphate pesticides in the children of agricultural workers. Indian J. Occup. Environ. Med. 14, 54, 2010.

4. SHARMA A., KUMAR V., KUMAR R., SHAHZAD B., KUMAR A., THUKRAL A.K., BHARDWAJ R. Brassinosteroid-mediated pesticide detoxification in plants: A mini-review. Cogent Food Agric. 4 (1), 1436212, 2018.

5. VIDYASAGAR G., KOTRESHA D., SREENIVASA N., RAMESH K. Role of endosulfan in mediating stress responses in Sorghum bicolor (L.) Moench. J. Environ. Biol. 30, 217, 2013.

6. SIDDIQUI Z.S., AHMED S. Combined effects of pesticide on growth and nutritive composition of soybean plants. J. Exp. Bot. 38721, 2006 
7. PARWEEN T., JAN S., MAHMOODUZZAFAR S., FATIMA S., SIDDIQUI Z.H. Selective effect of pesticides on plant-a review. Crit. Rev.Food Sci. Nutr. 56, 160, 2016.

8. SHARMA I., BHARDWAJ R., PATI P.K. Exogenous application of 28-homobrassinolide modulates the dynamics of salt and pesticides induced stress responses in an elite rice variety Pusa Basmati-1. J. Plant Growth Regul. 34, 509, 2015.

9. SINGH H., SINGH, N. B., SINGH A., HUSSAIN I., YADAV V. Physiological and biochemical e-ects of salicylic acid on Pisum sativum exposed to isoproturon. Arch. Agron. Soil Sci. 62, 1425, 2016.

10. COSKUN Y., KILIC S., DURAN R. E. The effects of the insecticide pyriproxyfen on germination, development and growth responses of maize seedlings. Fresenius Environ. Bull. 24, 278, 2015.

11. MAHMOOD Q., BILAL M., JAN S. Herbicides, pesticides, and plant tolerance: an overview. Emerging technologies and management of crop stress tolerance. 17, 423, 2014.

12. RAMEL F., SULMON C., SERRA A. A., GOUESBET G., COUEE I. Xenobiotic sensing and signalling in higher plants. J. Exp. Bot. 63, 3999, 2012.

13. SINGH P., PRASAD S. M. Antioxidant enzyme responses to the oxidative stress due to chlorpyrifos, dimethoate and dieldrin stress in palak (Spinacia oleracea L.) and their toxicity alleviation by soil amendments in tropical croplands. Sci. Total Environ. 630, 839, 2018.

14. XIAO X. M., CHENG Z. H., MENG H. W., KHAN M.A., $\mathrm{Li} H$. Intercropping with garlic alleviated continuous cropping obstacle of cucumber in plastic tunnel. Acta Agr. Sci. B Soil Plant Sci. 62, 696, 2012.

15. SEREME A., DABIRE C., KOALA M., SOMDA M. K., TRAORE A. S. Influence of organic and mineral fertilizers on the antioxidants and total phenolic compounds level in tomato (Solanum lycopersicum) Var. mongal F1. J. Exp. Biol. Agri. Sci. 4, 414, 2016.

16. SUN L., XUA H., SU W., XUE F., AN S., LU C, WU $\mathrm{R}$. The expression of detoxification geen in two maize cultivars by interaction of isoxadifen-ehtyl and nicosulfuron. Plant Physiol. Biochem. 129, 101, 2018.

17. LIU H., HUANG R., XIE F., ZHANG S., SHI J. Enantioselective phytotoxicity of metolachlor against maize and rice roots. J. Hazard. Mater. 217, 330, 2012a.

18. LIU X., QI C., WANG Z., LI Y., WANG Q., GUO M., CAO A. Effect of picloram herbicide on physiological responses of Eupatorium adenophorum Spreng. Chil. J. Agric. Res. 74, 438, 2014.

19. HABIBA U., ALI S., RIZWAN M., IBRAHIM M., HUSSAIN A., SHAHID M.R., ALAMRI S.A, ALYEMENI M. N., AHMAD P. Alleviative role of exogenously applied mannitol in maize cultivars differing in chromium stress tolerance. Environ.Sci. Pollut.Res. 1. 2019.

20. LICHTENTHALER H.K., WELLBURN A.R. Determinations of total carotenoids and chlorophylls a and b of leaf extracts in different solvents. 591, 1983.

21. AWAN J.A., SALIM U.R. Food analysis manual. Vet. Agric. Public. 5, 2, 1997.

22. DAUD M.K., MEI L., VARIATH M., ALI S., LI C., RAFIQ M., ZHU S. Chromium (VI) uptake and tolerance potential in cotton cultivars: effect on their root physiology, ultramorphology, and oxidative metabolism. Biomed. Res. Int. 2014.

23. VELIKOVA V., YORDANOV I., EDREVA A. Oxidative stress and some antioxidant systems in acid rain-treated bean plants: protective role of exogenous polyamines. Plant Sci. 151, 59, 2000.

24. BRADFORD M.M. A rapid and sensitive method for the quantitation of microgramquantities of protein utilizing the principle of protein dye binding. -Anal. Biochem. 72, 248, 1976.

25. DEY P.M. Oligosaccharides. In: Dey P.M., Harborne J.B. (eds.): Methods in Plant Biochemistry, Carbohydrates. Academic Press London. 2, 189, 1990.

26. BATES L., WALDREN R., TEARE I. Rapid determination of free proline for water-stress studies. Plant Soil. 39, 205, 1973.

27. ZHANG W., ZHANG F., RAZIUDDIN R., GONG H., YANG Z., LU L., YE Q., ZHOU W. Effects of 5-aminolevulinic acid on oilseed rape seedling growth under herbicide toxicity stress. J. Plant. Growth. Regul. 27, $159, \mathbf{2 0 0 8 b}$.

28. ALI B., MWAMBA T.M., GILL R.A., YANG C., ALI S., DAUD M.K., WU Y., ZHOU W. Improvement of element uptake and antioxidative defense in Brassica napus under lead stress by application of hydrogen sulfide. Plant Growth Regul. 74, 261, 2014.

29. DAUD M., VARIATH M., ALI S., NAJEEB U., JAMIL M., HAYAT Y., DAWOOD M., KHAN M.I., ZAFFAR M., CHEEMA S. A. Cadmium-induced ultramorphological and physiological changes in leaves of two transgenic cotton cultivars and their wild relative. J. Hazard. Mater. 168, 614, 2009.

30. SINGH G., SAHOTA H.K. Impact of benzimidazole and dithiocarbamate fungicides on the photosynthetic machinery, sugar content and various antioxidative enzymes in chickpea. Plant Physiol. Biochem. 132, 166, 2018.

31. SOMATRAKEN K., PRATUMNA S. Phytotoxicity of heptachlore and endosulfan sulfate contaminant in soil to economics crops. J. Environ. Biol. 33, 1097, 2012.

32. CHOUYCHAI W., LEE H. Phytotoxicity Assay of Crop Plants to Lindane and Alphaendosulfan Contaminants in Alkaline Thai Soil. Int. J. Agric. Biol. 14, 2012.

33. CHOUYCHAI W. Effect of some plant growth regulators on lindane and alpha-endosulfan toxicity to Brassica chinensis. J. Enviorn. Biol. 33, 811, 2012.

34. BALASUBRAMANIAN V., HILL J. Direct seeding of rice in Asia: emerging issues and strategic research needs for the 21st century. Direct seeding: Research strategies and opportunities, 15, 2002.

35. TUTEJA N., SOPORY S.K. Plant signaling in stress: G-protein coupled receptors, heterotrimeric G-proteins and signal coupling via phospholipases. Plant Signal Behav. 3, 79, 2008.

36. PETIT A.N., FONTAINE F., VASTA P., CLEMENT C., VAILlANT-GAVEAU N. Fungicide impacts on photosynthesis in crop plants. Photosynth. Res. 111, 315, 2012.

37. SALEM R.E.E.S. Side Effects of Certain Pesticides on Chlorophyll and Carotenoids Contents in Leaves of Maize and Tomato Plants. Middle East J. 5 (4), 566, 2016.

38. SHAKIR S.K., KANWAL M., MURAD W., UR REHMAN Z., UR REHMAN S., DAUD M.K., AZIZULLAH A. Effect of some commonly used pesticides on seed germination, biomass production and photosynthetic pigments in tomato (Lycopersicon esculentum). Ecotoxicology, 25 (2), 329, 2016.

39. YÜZBAŞIOĞLU E., DALYAN E. Salicylic acid alleviates thiram toxicity by modulating antioxidant enzyme capacity and pesticide detoxification systems in the tomato 
(Solanum lycopersicum Mill.). Plant Physiol. Biochem. 135, 322, 2019.

40. WANG J., LV M., ISLAM F., GILL R.A., YANG C., ALI B., YAN G., ZHOU W. Salcylic acid mediates antioxidant defense system and ABA pathway related gene expression in Oryza sativa against quinclorac toxicity. Ecotoxicol. Environ. Saf. 133, 146, 2016.

41. MITTON F.M., GONZALEZ M., MONSERRAT J.M., MIGLIORANZA K.S. Potential use of eidible crops in the phytoremediation of endosulfan residues in soil. Chemosphere. 148, 300, 2016.

42. FERREIRA L.C., SCAVRONI. J., DA SILVA J.R.V., CATANEO A.C., MARTINS D., BOARO. C.S.F. Copper oxychloride fungicide and its effect on growth and oxidative stress of potato plants. Pestic. Biochem.Physiol. 112, 63, 2014.

43. FATMA F., KAMAL A., SRIVASTAVA A. Exogenous application of salicylic acid mitigates the toxic effect of pesticides in Vigna radiata (L.) Wilczek. J. Plant Growth Regul. 37, 1185, 2018.

44. YILDIZTEKIN M., KAYA C., TUNA AL., ASHRAF M. Oxidative stress and antioxidative mechanisms in tomato (Solanum lycopersicum L.) plants sprayed with different pesticides. Pak J. Bot. 47, 717, 2015.

45. SINGH G., KAUR D. Studies on the antioxidative stress responses of fungicides carbendazim and mancozeb in seedlings of brassica (Brassica compestris L.). Int. Res. J. Environ. Sci. 5, 57, 2016.

46. CHRIS A., LUXMISHA G., MASIH J., ABRAHAM G. Growth, photosynthetic pigments and antioxidant responses of Azolla filiculoides to monocrotophos toxicity. J. Chem. Pharm. Res. 3, 381, 2011.

47. DEY A., DE J.N. Antioxidative potential of bryophytes: stress tolerance and commercial perspectives. a review. Pharmacologia. 3, 151, 2012.

48. NASRABADI M., GHAYAL N., DHUMAL KN. Effect of chloropyrifos and malathion on antioxidant enzymes in tomato and brinjal. Int. J. Pharm. Biol. Sci. 2, 2011.
49. LI P., SONG A.L., LI Z.J., FAN F.L., LIANG Y.C. Silicon ameliorates manganese toxicity by regulating manganese transport and antioxidant reactions in rice (Oryza sativa L.). Plant Soil. 354, 407, 2012.

50. XING F., LI Z., SUN A., XING D. Reactive oxygen species promote chloroplast dysfunction and salicylic acid accumulation in fumonisin B1-induced cell death. FEBS Lett. 587, 2164, 2013.

51. SHARMA S.S., DIETZ K.J. The significance of amino acids and amino acid-derived molecules in plant responses and adaptation to heavy metal stress. J. Expert. Bot. 57, 711, 2006

52. SHAKIR S.K., IRFAN S., AKHTAR B., UR REHMAN S., DAUD M. K., TAIMUR N., AZIZULLAH A. Pesticideinduced oxidative stress and antioxidant responses in tomato (Solanum lycopersicum) seedlings. Ecotoxicol. 1, 2018.

53. DRAGIČEVIĆ V., SIMIĆ M., STEFANOVIĆ L., SREDOJEVIĆ S. Possible toxicity and tolerance patterns towards post-emergence herbicides in maize inbred lines. Fresen. Environ. Bull. 19, 2010.

54. DUBEY R.K., TRIPATHI V., SINGH N., ABHILASH P.C. Phytoextraction and dissipation of lindane by Spinacia oleracea L. Ecotoxicol.Environ.Saf. 109, 22, 2014.

55. RANI R., KUMAR V., GUPTA P., CHANDRA A. Effect of endosulfan tolerant bacterial isolates (Delftia lacustris IITISM30 and Klebsiella aerogenes IITISM42) Klebsiella aerogenes IITISM42) with Helianthus annuus on remediation of endosulfan from contaminated soil. Ecotoxicol.Environ. Saf. 168, 315, 2019.

56. LIU H.J., XIONG M.Y., TIAN B.L. Comparative phytotoxicity of Rac-metolachlor and S-metolachlor on rice seedlings. J. Environ. Sci.Health, Part B. 47, 410, 2012b.

57. AKSOY O., DANE F. Ultrastructural changes in the root tip and leaf cells of Lens culinaris treated with fluazifopp-butyl. Turk. J. Bot. 35, 389, 2011. 